\title{
Cerebrospinal fluid creatine kinase in acutely psychotic patients $^{1}$
}

\author{
WILliaM A. MARTIN, RICHARD E. GAREY, AND ROBERT G. HEATH \\ From the Department of Psychiatry and Neurology, Tulane University School of Medicine, \\ New Orleans, Louisiana, U.S.A.
}

SUMMARY Significantly elevated serum creatine phosphokinase concentrations have been demonstrated in $70 \%$ of patients with acute psychosis. Elevations in spinal fluid creatine phosphokinase (CPK) activity have been reported in several neurological diseases, often in association with otherwise normal routine spinal fluid studies. Spinal fluid and serum were obtained simultaneously from of 11 patients with acute psychosis, the majority being schizophrenic. Although the serum CPK was $\vec{\circ}$ elevated in eight of the 11 subjects, spinal fluid glucose, protein, colloidal gold, and CPK were normal in all cases. The theoretical implications of these results are discussed.

An increase in serum creatine phosphokinase (CPK) concentration in acutely psychotic patients of varying diagnostic types has been repeatedly demonstrated by Meltzer (1968, 1969), Meltzer and Moline (1970a, 1970b) and confirmed by Coffey, Heath, and Guschwan (1970). Available evidence indicates that increased activity of serum CPK (type III) is not due to orally or intramuscularly administered medication, physical activity, emotional stress in a non-psychotic process, weight loss, hypersecretion of steroids or adrenaline or muscle tension (Meltzer and Moline, 1970b). Recent histochemical and electron microscopic studies on muscle biopsies revealed that $62 \%$ of psychotic patients had morphological evidence of myopathy (Fischman, Meltzer, and Poppei, 1970; Meltzer and Engel, 1970). An exaggerated increase in serum enzymes after a standardized exercise test was found in $45 \%$ of psychotic subjects (Meltzer and Moline, 1970a). Although there is no clinically detectable weakness in these patients, the possibility of a subclinical myopathy as part of a more diffuse organic disturbance affecting the nervous system has been suggested (Meltzer and Moline, 1970b).

Creatine phosphokinase catalyzes the reversible reaction: creatine phosphate $+\mathrm{ADP} \rightleftharpoons$ creatine + ATP. It is present in high concentration in

1 Supported in part by a grant-in-aid from the Scottish Rite Foundation. brain (type I), cardiac muscle (type II), and skeletal muscle (type III). The isoenzymes do not $\mathrm{ur}$ cross react immunologically and may be identE $N$ fied by electrophoresis. Type II and III is $\overrightarrow{8} \circ$ enzymes, derived from muscle, are found exclusively in the serum. The isoenzyme found spinal fluid corresponds to that of brain (type and its concentration in the spinal fluid is ind pendent of both serum enzyme activity and spinal fluid protein. Neither the brain noै muscle isoenzyme crosses the blood brain barrier ? in significant amounts (Sherwin, Norris, and Bulcke, 1969). In brain, CPK plays an important role in cerebral metabolism by maintaining adenosine triphosphate concentrations at the $\frac{0}{\not}$ expense of the creatine phosphate reservoir. This function is important not only in maintaining the nerve cell membrane potential but is also required in active transport of substrate into cells (Davison and Dobbing, 1968).

In this study, both the serum and spinal fluid CPK activity of acutely psychotic patients was: simultaneously measured. Since elevation of 3 spinal fluid CPK occurs in a number of neuro- $\delta$ logical diseases, often with otherwise normal CSF studies (Sherwin et al., 1969), we sought to응 determine if this might occur in psychosis as well.

\section{METHODS}

Acutely psychotic patients hospitalized on the 
Tulane psychiatry service of Charity Hospital were studied 24 to 72 hours after admission. The subjects were randomly selected without regard to diagnostic classification or previous psychiatric history. The study group consisted of six females and five males ranging in age from 18 to 72 years. Patients were receiving oral drugs and psychotherapy as indicated, as well as normal hospital diet.

Lumbar puncture was performed in the lateral recumbent position. Cell count, glucose and protein determination, and colloidal gold curves of the cerebrospinal fluid were performed by the Charity Hospital laboratories, using standard techniques. Samples of serum obtained at the time of lumbar puncture as well as spinal fluid were immediately frozen at $-20^{\circ} \mathrm{C}$. Creatine kinase was measured spectrophotometrically at $30^{\circ} \mathrm{C}$ using a CPK StatPack kit (Calbiochem, Los Angeles, California). Standardization and reproducibility of this procedure have been described previously (Coffey et al., 1970).

Serum glutamic oxalacetic transaminase (SGOT) was measured in the Charity Hospital laboratories as part of a biochemical screening procedure. Blood for this procedure was drawn independently, usually shortly after admission, and SGOT determined by the method of Morgenstern, Oklander, Auerbach, Kaufman, and Klein (1966).

All hospital records were reviewed at the time of discharge; the final clinical diagnosis was then correlated with routine spinal fluid studies, spinal fluid and serum CPK and serum SGOT values.

\section{RESULTS}

The Table illustrates the patient's sex, diagnosis, routine spinal fluid studies, spinal fluid and serum enzyme values. Spinal fluid glucose, protein, and colloidal gold curves were normal in all patients. There was no measurable spinal fluid creatine kinase activity in any patient, regardless of diagnosis, time lapse between onset of symptoms and lumbar puncture, absence or use of medication, or the level of the serum CPK at the time of the procedure.

The serum CPK, however, was unequivocally elevated in eight of the 11 patients $(73 \%)$, the normal values being 5-50 $\mathrm{mU} / \mathrm{ml}$. for males and 5-30 $\mathrm{mU} / \mathrm{ml}$. for females. Three females had values in $30-40 \mathrm{mU} / \mathrm{ml}$. range, which is considered equivocal. It is significant, however, that each of these patients had an 'atypical' feature in their clinical diagnoses, one being chronically schizophrenic as well as acutely psychotic, another having depressive symptoms, and the third having cerebral atrophy demonstrated by pneumoencephalography.

Serum SGOT activity was mildly elevated in four of eight patients. There was no correlation between the degree of elevation of the two serum enzymes. Patient P.M. whose SGOT was 147 units/ml. also had a bilirubin of $1.5 \mathrm{mg} / 100 \mathrm{ml}$. and a history of drug abuse suggesting that hepatic pathology was contributory.

In general the results of the serum enzyme studies are in agreement with published reports. The large number $(73 \%)$ of patients with increased serum CPK activity probably reflects

TABLE

SPINAL FLUID, GLUCOSE, PROTEIN, COLLOIDAL GOLD CURVE AND CPK COMPARED WITH SERUM CPK AND SGOT IN ACUTELY PSYCHOTIC SUBJECTS

\begin{tabular}{|c|c|c|c|c|c|c|c|c|}
\hline \multirow[t]{2}{*}{ Patient } & \multirow[t]{2}{*}{ Sex } & \multirow[t]{2}{*}{ Diagnosis } & \multicolumn{4}{|c|}{ Cerebrospinal fluid } & \multicolumn{2}{|c|}{ Serum } \\
\hline & & & $\begin{array}{c}\text { Glucose } \\
(m g / 100 m l .)\end{array}$ & $\begin{array}{c}\text { Protein } \\
(m g / 100 \mathrm{ml} .)\end{array}$ & Coll. gold & $\begin{array}{c}C P K \\
(m U / m l .)\end{array}$ & $\begin{array}{c}C P K \\
(m U / m l .)\end{array}$ & $\begin{array}{c}\text { SGOT } \\
(\text { Karmen } u . / m l .)\end{array}$ \\
\hline 1. M.C. & $\mathbf{M}$ & Paranoid schiz. & 65 & 27 & 0000000000 & 0 & 385 & - \\
\hline 2. R.D. & $\mathrm{F}$ & Paranoid schiz. & 68 & 16 & 0000000000 & 0 & 574 & 65 \\
\hline 3. C.R. & $\mathbf{M}$ & Paranoid schiz. & 68 & 16 & 0000000000 & 0 & 420 & 50 \\
\hline 5. P.M. & $\mathbf{M}$ & $\begin{array}{l}\text { Paranoid schiz., drug } \\
\text { abuse }\end{array}$ & 69 & 36 & 0110000000 & 0 & 830 & 147 \\
\hline 6. E.C. & $\mathbf{F}$ & $\begin{array}{l}\text { Paranoid schiz., acute } \\
\text { and chronic }\end{array}$ & 75 & 42 & 0000000000 & 0 & 31 & 30 \\
\hline 7. J.C. & $\mathbf{M}$ & Catatonic schiz. & 58 & 31 & 0000000000 & 0 & 232 & 95 \\
\hline 8. A.S. & $F$ & Undiff. schiz. & 66 & 27 & 0000000000 & 0 & 385 & 一 \\
\hline 9. S.K. & $\mathbf{M}$ & Undiff. schiz. & 70 & 37 & 0000000000 & 0 & 110 & 43 \\
\hline 10. J.E. & $\mathbf{F}$ & Schiz. and depression & 80 & 25 & 0000000000 & 0 & 38 & - \\
\hline 11. M.R. & $\mathrm{F}$ & $\begin{array}{l}\text { Cerebral atrophy, } \\
\text { psychosis }\end{array}$ & 65 & 36 & 0000000000 & 0 & 32 & 35 \\
\hline
\end{tabular}


the grossly psychotic state of the patients when studied shortly after admission.

\section{DISCUSSION}

Although increased serum CPK activity has classically been associated with skeletal or cardiac muscle disease (Pearce, Pennington, and Walton, 1964), it is now quite apparent that it is a fairly consistent finding in acute psychosis. This finding is difficult to explain, since most psychotic patients exhibit no muscle weakness, atrophy, or fasciculation, and have normal electromyograms and creatine index (Meltzer and Moline, 1970b). Although histochemical and electron microscopic alterations have been reported, these findings have been limited to 0.05 to $1 \%$ of the total number of fibres in the biopsy (Meltzer and Engel, 1970) and represent rather non-specific morphological changes (Fischman et al., 1970).

The question then arises, in what way does the alteration in mental activity correspond to altered serum enzyme activity? One possible explanation would be that the increased muscular activity in agitated patients causes increased enzyme activity, much as it does in anyone subjected to strenuous muscle exercise (Fowler, Gardner, Kazerunian, and Lauvstad, 1968). Meltzer and Moline (1970a) have refuted this theory, pointing to the prolonged elevations of months' duration seen in psychotic patients in contrast with normal CPK values in tense neurotic subjects. Furthermore, he demonstrated that approximately half of previously psychotic patients have an exaggerated rise in serum CPK after a standard exercise test, and that an exaggerated response may be seen in close relatives as well. Since abnormal exercise tolerance is also demonstrable in patients with muscular dystrophy and their relatives (Hudgson, Gardner-Medwin, and Pennington, 1967), the question of a homologous constitutional predisposition to both psychosis and myopathy has been raised (Meltzer and Moline, 1970b).

Other investigators have found, however, that the serum CPK in normal subjects fluctuates considerably during bicycle exercise at different work loads without any relationship to duration, intensity, or total work performed. Furthermore, enzyme levels obtained during normal daily activity in patients with muscular dystrophy are often higher than the levels induced either by $z$

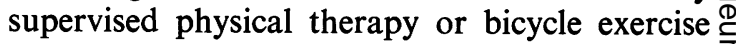
(Fowler et al., 1968). These observations would tend to confuse the interpretation of exercise tolerance tests and their significance when 0 applied to psychosis or dystrophy. It would appear that, in the absence of any clinical evidence of myopathy, even in repeatedly psychotic $\stackrel{2}{\xi}$ patients, further understanding of the pathophysiology of increased serum enzyme activity is necessary before any conclusions can be drawn.

If acute psychosis is considered an acquired process associated with an increase in a subfraction of immunoglobulin-that is, taraxein (Heath, Guschwan, and Coffey, 1970), then per- ڤ haps both muscle and brain are conjointly $\overrightarrow{0}$ affected by a common immunological mechanism. It is interesting in this respect, that both $\vec{\omega}$ elevated serum CPK and taraxein are found only in acutely psychotic subjects but not in chronic $\overline{0}$ schizophrenics or patients in remission. The pathophysiology of such an immunologicat or mechanism is largely speculative, but may bo요 similar to that postulated for the neuromyof pathies and encephalomyelopathies described i association with remote or occult carcinomas (Wilkinson and Zeroniski, 1965). Although the 웡 increase in serum CPK might theoretically be secondary to leakage of the enzyme througe muscle membranes immunologically altered b taraxein, the absence of elevated CPK levels in the CSF would militate against a similar neuronal membrane permeability in the brain. Although taraxein does alter membrane potential of neurones in the septal region of normal monkeys, producing focal electroencephalographic changes as well as behavioural effects, it remains to be demonstrated that either the elevated serum enzymes or the focal electrophysiological alterations are immunological in aetiology or that they even share some basic pathophysiological mechanism.

Finally, it may be proposed that both the increase in serum enzymes and clinical psychosis are secondary to a primary pathological process within the central nervous system. An analogous example would be cerebrovascular thrombosis. About two thirds of patients with cerebrovascular thrombosis develop increase in serum CPK 응 levels, maximum at 48 to 72 hours after the $N$ 
stroke. Values as high as 2,900 units per $\mathrm{ml}$. have been reported. The CPK slowly returns to normal over a two week period (Acheson, Hutchison, and Westhead, 1965; Wolintz, Jacobs, Christoff, Solomon, 1969). About 50\% of stroke patients also have an increase in spinal fluid CPK activity (Eisen and Sherwin, 1968). The level of CPK activity in the serum and spinal fluid are quite independent of each other, since neither isoenzyme crosses the blood brain barrier in significant amounts (Eisen and Sherwin, 1968). Since the lesion in a stroke patient is clearly within the brain, and muscle activity is markedly curtailed in the acute state, the increase in serum CPK may reflect an alteration in muscle structure or chemistry due to loss of tonic supranuclear neuronal influences. If a similar central neural malfunction is responsible for psychosis with increased serum enzyme activity, localization of the disorder by currently available clinical or diagnostic techniques is still to be established. In addition, this study has demonstrated that both routine CSF studies and spinal fluid CPK activity are normal in socalled functional psychosis, in contrast with abnormal values found in a number of differing neuropathological processes-for example, neoplastic, demyelinating, infarction, GuillainBarré syndrome, epilepsy, and meningitis (Sherwin et al., 1969).

On reviewing the evidence, it appears that the possibility of an immunological disorder, operative in both the psychotic process and in increasing serum enzymes derived from muscle, has not been extensively investigated. Further studies into this possibility are being conducted.

\section{REFERENCES}

Acheson, J., James, D. C., Hutchinson, E. C., and Westhead, R. (1965). Serum-creatine-kinase levels in cerebral vascular disease. Lancet, 1, 1306-1307.
Coffey, J. W., Heath, R. G., and Guschwan, A. F. (1970). Serum creatine kinase, aldolase, and copper in acute and chronic schizophrenics. Biological Psychiatry, 2, 331-339.

Davison, A. N., and Dobbing, J. (1968). Applied Neurochemistry, p. 229. Blackwell: Oxford.

Eisen, A. A., and Sherwin, A. L. (1968). Serum creatine phosphokinase activity in cerebral infarction. Neurology (Minneap.), 18, 263-268.

Fischman, D. A., Meltzer, H. Y., Poppei, R. W. (1970). Disruption of myofibrils in the skeletal muscle of psychotic patients. Archives of General Psychiatry, 23, 503-515.

Fowler, W. M., Gardner, G. W., Kazerunian, H. H., and Lauvstad, W. A. (1968). The effect of exercise on serum enzymes. Archives of Physical Medicine and Rehabilitation, 49, 554-565.

Heath, R. G., Guschwan, A. F., and Coffey, J. W. (1970). Relation of taraxein to schizophrenia. Diseases of the Nervous System, 31, 391-395.

Hudgson, P., Gardner-Medwin, D., Pennington, R. J. T., and Walton, J. N. (1967). Studies of the carrier state in the Duchenne type of muscular dystrophy: part I. Effect of exercise on serum creatine kinase activity. Journal of Neurology, Neurosurgery, and Psychiatry, 30, 416-419.

Meltzer, H. Y. (1968). Creatine kinase and aldolase in serum: abnormality common to acute psychoses. Science, 159, 1368-1370.

Meltzer, H. Y. (1969). Muscle enzyme release in the acute psychoses. Archives of General Psychiatry, 21, 102-112.

Meltzer, H. Y., and Engel, W. K. (1970). Histochemical abnormalities of skeletal muscle in acutely psychotic patients: Part II. Archives of General Psychiatry, 23, 492502.

Meltzer, H. Y., and Moline, R. (1970a). Plasma enzymatic activity after exercise. Study of psychiatric patients and their relatives. Archives of General Psychiatry, 22, 390-397.

Meltzer, H. Y., and Moline, R. (1970b). Muscle abnormalities in acute psychoses. Archives of General Psychiatry, 23, 481-491.

Morgenstern, S., Oklander, M., Auerbach, J., Kaufman, J., and Klein, B. (1966). Automated determination of serum glutamic oxaloacetic transaminase. Clinical Chemistry, 12, 95-111.

Pearce, J. M. S., Pennington, R. J., and Walton, J. N. (1964). Serum enzyme studies in muscle disease. Part II. Serum creatine kinase activity in muscular dystrophy and in other myopathic and neuropathic disorders. Journal of Neurology, Neurosurgery, and Psychiatry, 27, 96-99.

Sherwin, A. L., Norris, J. W., and Bulcke, J. A. (1969) Spinal fluid creatine kinase in neurologic disease. Neurology (Minneap.), 19, 993-999.

Wilkinson, P. C., and Zeromski, J. (1965). Immunofluorescent detection of antibodies against neurones in sensory carcinomatous neuropathy. Brain, 88, 529-538.

Wolintz, A. H., Jacobs, L. D., Christoff, N., Solomon, M., and Chernik, N. (1969). Serum and cerebrospinal fluid enzymes in cerebrovascular disease. Archives of Neurology, 20, 54-61. 